\title{
CLINICAL STUDY OF THE DISEASE OF CALVES ASSOCIATED WITH MYCOPLASMA BOVIS INFECTION
}

\author{
L. STIPKOVITS ${ }^{1 *}$, P. RIPLEY ${ }^{2}$, J. VARGA ${ }^{3}$ and V. PÁLFI ${ }^{4}$ \\ ${ }^{1}$ Veterinary Medical Research Institute of the Hungarian Academy of Sciences, H-1581 \\ Budapest, P.O. Box 18, Hungary; ${ }^{2}$ Novartis Animal Health UK Ltd, Camberley, Surrey, \\ UK; ${ }^{3}$ Department of Microbiology and Infectious Diseases, University of Veterinary \\ Science, Budapest and ${ }^{4}$ Central Veterinary Institute, Budapest, Hungary
}

(Received March 28, 2000; accepted October 17, 2000)

Clinical, bacteriological and serological examination of 35 calves from the age of 5 to 26 days was performed in a Holstein-Friesian dairy herd endemically infected with Mycoplasma bovis. M. bovis was isolated from $48.6 \%$ of nasal swabs taken from the calves at the age of 5 days, and from $91.4 \%$ of the same calves at the age of 26 days, indicating the gradual spread of infection. The isolation rate of Pasteurella multocida did not change much, and varied from 28.6 to $25.7 \%$. No P. haemolytica could be detected. In addition to M. bovis and P. multocida, the herd was also infected with different viruses (including bovine viral diarrhoea virus, infectious bovine rhinotracheitis virus, bovine adenoviruses, parainfluenza-3 virus, and bovine respiratory syncytial virus) as a large proportion of the sera of newborn calves contained colostral antibodies against these viruses. In most of the newborn calves severe clinical signs (fever, depression, inappetence, hyperventilation, dyspnoea, nasal discharge and coughing) due to $M$. bovis infection developed. The clinical signs appeared already on the fifth day of life, and their incidence was the highest at the age of 10 to 15 days. Three calves $(8.6 \%)$ died as a result of severe serofibrinous pneumonia. The surviving calves showed very poor weight gain (ranging from 1.5 to $3.5 \mathrm{~kg}$ ) during the first two weeks of life.

Key words: Mycoplasma bovis, infection, calf, clinical signs, bacteriology, epidemiology

Mycoplasma bovis was first isolated from cases of severe mastitis in cattle in the USA (Hale et al., 1962). Mastitis associated with M. bovis was detected in several countries including Hungary (Horváth et al., 1981). The role of M. bovis in mastitis was also confirmed by experimental infection (Brownlie et al., 1976). $M$. bovis infection was also incriminated in reproductive disorders of cows (endometritis, salpingitis, reduction of conception rate, abortion) (Hirth et al., 1966) as well as in bulls with seminal vesiculitis, epididymitis and orchitis (Lein,

\footnotetext{
"E-mail: stipkovits@novell.vmri.hu; Fax: +36 (1) 467-4083; +36 (1) 252-1076
} 
1974), impaired spermatozoa motility (Jurmanova and Sterbova, 1977), and low fertilization rate (Kissi et al., 1985).

Significant increase of calf mortality due to pneumonia and arthritis (Romváry et al., 1975; Langford, 1977) and sometimes meningitis (Stipkovits et al., 1993) was also attributed to M. bovis. However, relatively few data are available on the epidemiological and clinical appearance of the disease caused by $M$. bovis.

The aim of this study was to observe the epidemiological features and clinical signs of the disease of young calves in an endemically infected herd, along with the isolation of $M$. bovis from the nasal discharge of affected calves. Attention was also paid to the presence of bacteria.

\section{Materials and methods}

\section{Herd history}

The commercial dairy herd where the study was carried out consisted of about 450 Holstein-Friesian cows and about 500 growing heifers. Young males were generally sold at the age of three weeks and females were kept as replacements for complementing the cow herd. The herd had been kept closed already for about ten years, no animals from other herds had been introduced to the farm. About 5-6 years ago a very significant (20-30\%) mortality of calves younger than 1 month was observed every month in association with $M$. bovis infection. As at that time vaccination against various virus infections did not reduce the mortality of young calves, vaccination was stopped and a regular prophylactic treatment of calves was performed using antimycoplasma antibiotics which reduced mortality below 5\%; however, M. bovis could constantly be isolated. To perform our study this prophylactic treatment of the animals was temporarily suspended.

All newborn calves received colostrum from their dams within $2 \mathrm{~h}$ after birth. At 4 days of age the calves were identified by ear-tags and placed into individual Steinmann pens outside the building. The distance between the rows of pens was 6 metres, while the distance between pens was $2 \mathrm{~m}$. The animals were fed twice a day. During the first 8 days the animals were fed with whole milk, while later on with milk diluted with water in a ratio of $1: 2$. From day 10 the animals were offered premix and lucerne hay quantum satis.

\section{Animals, bacteriological and serological examinations}

Altogether 35 calves, born from the beginning of November 1997 till the end of January 1998, were included in the study. The observation of the calves was started at the age of 5 days and continued up to 26 days of age (length of ob- 
servation period: 21 days). Six consecutively born animals represented a batch of calves and data of these batches were compared with each other.

Nasal swab samples from 12 newborn calves, vaginal swabs before the beginning of the study from their mothers, nasal swabs at the age of 5 and 26 days of age from all 35 calves included in the study were taken and cultured for M. bovis and Pasteurella multocida. Another 35 calves which were not examined clinically, were examined for these microorganisms only at 5 days of age. Animals that died during the observation period were necropsied, and the gross pathological and histological lesions were observed and scored. The lungs, liver, spleen and kidney of these animals were also examined bacteriologically.

For the isolation of M. bovis medium B (Ernø and Stipkovits, 1973a) was used. Isolates were identified according to the biochemical properties of cloned strains (Ernø and Stipkovits, 1973b) as well as by epifluorescence and immunoperoxidase staining of colonies (Bencina and Bradbury, 1992). For culturing P. multocida sheep blood agar was used. Isolates were identified on the basis of their morphological and biochemical characteristics.

Blood samples taken from 15 calves at the age of 5 days were examined for the presence of antibodies against bovine viral diarrhoea (BVD) virus, bovine respiratory syncytial (RS) virus and infectious bovine rhinotracheitis (IBR) virus by the virus neutralization (VN) test, while antibodies against bovine adenoviruses and parainfluenza-3 virus were detected by agar gel immunodiffusion (AGID) test or by haemagglutination inhibition (HI) test, respectively.

\section{Clinical assessment}

The rectal temperature of each calf was taken every morning at the same time during the whole observation period. Body temperature higher than $39.5^{\circ} \mathrm{C}$ was regarded as fever.

The clinical status of the animals, general clinical appearance, type and rate of respiration, presence of nasal discharge, severity of cough, clinical signs of arthritis were examined every day and scored from 0 to 4 according to their severity. Amount of milk consumed and occasions when animals refused to take the whole quantity of milk offered were recorded every day, evaluated statistically (Chi-square test) and compared to other batches of calves.

Animals having fever, severe clinical signs or decreased appetite were treated symptomatically with various drugs. The number of treatments in batches during the whole observation period was evaluated and compared.

Animals were weighed before the start of the experiment, at the age of 14 and 26 days. Average body weight gains of calves in each batch in periods from 5 to 14 and from 15 to 26 days of age were evaluated statistically (Student's $t$ test) and compared. 


\section{Results}

\section{Prevalence of infection}

The results showed that the test herd was infected with $M$. bovis, $P$. multocida and different viruses. The presence of $M$. bovis was demonstrated in 2 out of 12 vaginal swabs of cows and in the nasal cavity of 31 out of $70(44.3 \%) 5$-dayold calves. In addition to this a disease characteristic of $M$. bovis was observed in the herd. Among 70 cows, the mothers of calves examined, 19 (27.1\%) had retention of fetal membranes, while 5 cows developed mastitis. During the experimental period one abortion and 2 stillbirths occurred.

The herd was also infected with P. multocida, which could be cultured from the nasal swabs of 17 out of 48 calves (35.4\%). However, the test herd was not infected with $P$. haemolytica, as that organism could not be isolated from any of the samples.

The serological examination of blood samples of 15 calves, taken at 5 days of age, showed that all sera contained maternal antibodies against parainfluenza-3 virus (in titres ranging from 1:20 to 1:320), nine animals had antibodies against IBR virus, six against adenoviruses (both subgroups), five animals were positive for antibodies against BVD virus and one for antibodies to RS virus.

M. bovis could be isolated from $48.6 \%$ of the nasal swabs taken from calves at the age of 5 days, but 26 days of age already $91.4 \%$ of the animals had M. bovis in the nasal cavity (Table 1). Infection rate in each batch was similar at an early age and slightly increased at an older age. Increase of the isolation rate for all animals was statistically significant. The isolation rate of $P$. multocida from the nasal cavity was similar at an early and at a later age; however, a remarkable variation (from 0 to 6 ) was seen in different batches of calves.

\section{Table 1}

Rate of isolation of Mycoplasma bovis and Pasteurella multocida from the nasal cavity of calves

\begin{tabular}{|c|c|c|c|c|}
\hline \multirow{2}{*}{ No. of batches of calves } & \multicolumn{2}{|c|}{ M. bovis } & \multicolumn{2}{|c|}{ P. multocida } \\
\hline & At 5 days old & At 26 days old & At 5 days old & At 26 days old \\
\hline 1 & $4 / 6^{*}$ & $6 / 6$ & $6 / 6$ & $5 / 6$ \\
\hline 2 & $2 / 6$ & $6 / 6$ & $1 / 6$ & $3 / 6$ \\
\hline 3 & $3 / 6$ & $6 / 6$ & $1 / 6$ & $1 / 6$ \\
\hline 4 & $2 / 6$ & $6 / 6$ & $1 / 6$ & $0 / 6$ \\
\hline 5 & $4 / 6$ & $5 / 6$ & $1 / 6$ & $0 / 6$ \\
\hline 6 & $2 / 5$ & $3 / 5$ & $0 / 5$ & $0 / 5$ \\
\hline Total & $17 / 35$ & $32 / 35$ & $10 / 35$ & $9 / 35$ \\
\hline (From November to January) & $48.6 \%$ & $91.4 \%$ & $28.4 \%$ & $25.7 \%$ \\
\hline $\begin{array}{l}\text { Chi-square test between first and } \\
\text { second examination }\end{array}$ & - & $\mathrm{P}<0.001$ & - & Not significant \\
\hline
\end{tabular}

${ }^{*}$ Number of calves infected/examined 


\section{Clinical assessment of calves}

The proportion of clinically affected calves was very high (Table 2). However, by comparing the number of disease days and scores of signs significant differences were observed between batches of calves. On the basis of scores the highest incidence of clinical symptoms was seen in the 1st and 2nd as well as in the 6 th batch. Signs of depression and reluctance to rise were observed already at the age of 5-7 days and their incidence increased by the age of 10-15 days and continued for 4-5 days. Scores of clinical signs also increased gradually until that age. The higher average scores indicated more severe signs of the disease.

Respiratory signs were present in fewer animals than general clinical signs. When animals of different batches were compared, very significant differences were observed between them (Table 2). The tendency of their incidence and severity was similar as that of the general clinical signs. They were observed mostly during the first 15 days of life.

\section{Table 2}

Number of calves showing general clinical signs, respiratory signs and nasal discharge, number of disease days and scores in different batches of calves

\begin{tabular}{|c|c|c|c|c|c|c|c|c|c|}
\hline \multirow{2}{*}{$\begin{array}{c}\text { No. } \\
\text { of batches } \\
\text { of calves }\end{array}$} & \multicolumn{3}{|c|}{ General clinical signs } & \multicolumn{3}{|c|}{ Respiratory signs } & \multicolumn{3}{|c|}{ Nasal discharge } \\
\hline & $\begin{array}{l}\text { No. of } \\
\text { calves }\end{array}$ & $\begin{array}{l}\text { No. of } \\
\text { disease } \\
\text { days }\end{array}$ & Scores & $\begin{array}{l}\text { No. of } \\
\text { calves }\end{array}$ & $\begin{array}{l}\text { No. of } \\
\text { disease } \\
\text { days }\end{array}$ & Scores & $\begin{array}{l}\text { No. of } \\
\text { calves }\end{array}$ & $\begin{array}{c}\text { No. of } \\
\text { disease } \\
\text { days }\end{array}$ & Scores \\
\hline 1 & $6 / 6^{*}$ & 31 & 36 & $5 / 6$ & 13 & 15 & $6 / 6$ & 53 & 52 \\
\hline 2 & $6 / 6$ & 33 & 47 & $4 / 6$ & 7 & 11 & $6 / 6$ & 42 & 57 \\
\hline 3 & $3 / 6$ & 6 & 11 & $2 / 6$ & 4 & 8 & $5 / 6$ & 18 & 27 \\
\hline 4 & $5 / 6$ & 15 & 25 & $2 / 6$ & 7 & 14 & $5 / 6$ & 17 & 19 \\
\hline 5 & $4 / 6$ & 12 & 22 & $3 / 6$ & 7 & 14 & $4 / 6$ & 14 & 19 \\
\hline 6 & $4 / 5$ & 18 & 34 & $4 / 5$ & 7 & 13 & $5 / 5$ & 43 & 56 \\
\hline Total & $28 / 35$ & $115 / 735$ & 175 & $20 / 35$ & $45 / 735$ & 75 & $31 / 35$ & $187 / 735$ & 230 \\
\hline $\begin{array}{l}\text { (From Novem- } \\
\text { ber to January) }\end{array}$ & $80.0 \%$ & $15.6 \%$ & & $57.14 \%$ & $6.1 \%$ & & $88.57 \%$ & $25.4 \%$ & \\
\hline
\end{tabular}

${ }^{*}$ Number of calves infected/examined

Nasal discharge was observed in relatively many calves immediately after starting the study and it continued for about 15 days. Variation was noticed in respect of this sign between calves of different batches. For instance, in batches 1, 2 and 6, a high number of calves showed nasal discharge and the scores were also high, while in batches 3, 4 and 5 calves did not produce much discharge.

Coughing of animals was generally mild, the average scores were 1.2-1.7. Enlargement of joints as well as abnormal standing of legs were seen frequently. However, increase of local temperature, accumulation of fluid in joints, and pain 
were not seen, therefore these signs were not regarded as arthritis. Typical arthritis was observed rarely, only in calves in batch 1 . The average lesion score was 1.2.

Increase of rectal temperature over $39.5^{\circ} \mathrm{C}$ was observed in $80.0 \%$ of calves (Table 3). Variation in days with high temperature was also significant. Days with higher temperature started on the 5th day of life and reached the highest incidence at the age of 11-16 days.

Many animals (71.4\%) were affected with temporary inappetence (Table 3). By comparing this parameter in calves of different batches, significant variations were noticed. Refusing of a certain quantity of milk was already observed on the first day of the observation period at the age of five days. Later on occasions of milk refusal increased, to the highest incidence on days 12-16 of life.

A high number of animals (94.3\%) had to be treated (Table 3). Similar results were obtained by comparing these parameters in animals of different batches. The number of individual treatments as well as the number of treatment days were at the highest level between 8 and 16 days.

Table 3

Number of calves with elevated $\left(\geq 39.5^{\circ} \mathrm{C}\right)$ rectal temperature, inappetence (milk refusal) and receiving treatment in different batches

\begin{tabular}{|c|c|c|c|c|c|c|}
\hline \multirow{2}{*}{$\begin{array}{c}\text { No. } \\
\text { of batches } \\
\text { of calves }\end{array}$} & \multicolumn{2}{|c|}{ Elevated rectal temperature } & \multicolumn{2}{|c|}{ Inappetence } & \multicolumn{2}{|c|}{ Treatments } \\
\hline & $\begin{array}{c}\text { No. } \\
\text { of calves }\end{array}$ & $\begin{array}{l}\text { No. } \\
\text { of disease } \\
\text { days }\end{array}$ & $\begin{array}{c}\text { No. } \\
\text { of calves }\end{array}$ & $\begin{array}{c}\text { No. } \\
\text { of days }\end{array}$ & $\begin{array}{c}\text { No. } \\
\text { of calves }\end{array}$ & $\begin{array}{c}\text { No. } \\
\text { of treatment } \\
\text { days }\end{array}$ \\
\hline 1 & $6 / 6$ & 41 & $4 / 6$ & 25 & $6 / 6$ & 25 \\
\hline 2 & $5 / 6$ & 40 & $5 / 6$ & 38 & $5 / 6$ & 22 \\
\hline 3 & $3 / 6$ & 23 & $5 / 6$ & 22 & $5 / 6$ & 15 \\
\hline 4 & $6 / 6$ & 54 & $3 / 6$ & 3 & $6 / 6$ & 14 \\
\hline 5 & $5 / 6$ & 24 & $3 / 6$ & 14 & $6 / 6$ & 18 \\
\hline 6 & $3 / 5$ & 11 & $5 / 5$ & 42 & $5 / 5$ & 23 \\
\hline Total (from No- & $28 / 35$ & $193 / 735$ & $25 / 35$ & $144 / 735$ & $33 / 35$ & $117 / 735$ \\
\hline vember to January) & $80.0 \%$ & $26.3 \%$ & $71.4 \%$ & $19.6 \%$ & $94.3 \%$ & $15.9 \%$ \\
\hline
\end{tabular}

Body weights of individual calves at the beginning of the observation period varied between 29.0 and $46.0 \mathrm{~kg}$, while average body weights of calves belonging to different batches ranged from 40.8 to $46.0 \mathrm{~kg}$ (Table 4). Generally there were no statistically significant differences between the batches. Body weight gains at the age of 5-14 days varied from 1.50 to $3.50 \mathrm{~kg}$. Relatively higher body weight gains $(2.60-5.92 \mathrm{~kg})$ were recorded in the observation period from 15 to 26 days, but they were generally very poor $(4.50-7.50 \mathrm{~kg})$ taking into account the whole observation period. In this respect again significant differences were noticed between different batches. 
Table 4

Initial body weights and weight gains of calves during the observation period in different batches

\begin{tabular}{ccccc}
\hline $\begin{array}{c}\text { No. } \\
\text { of batches } \\
\text { of calves }\end{array}$ & $\begin{array}{c}\text { Body weight } \\
\text { at the beginning } \\
\text { of observation }\end{array}$ & $\begin{array}{c}\text { Body weight gain } \\
\text { between day 5 and } \\
\text { 14 of life }\end{array}$ & $\begin{array}{c}\text { Body weight gain } \\
\text { between day 15 and 26 } \\
\text { of life }\end{array}$ & $\begin{array}{c}\text { Body weight gain } \\
\text { between day } 5 \text { and } \\
26 \text { of life }\end{array}$ \\
\hline 1 & $43.40 \pm 5.4$ & $1.50 \pm 1.0$ & $5.92 \pm 1.5$ & $7.42 \pm 0.9$ \\
2 & $42.40 \pm 2.7$ & $3.50 \pm 1.4$ & $4.50 \pm 2.4$ & $8.00 \pm 2.2$ \\
3 & $41.25 \pm 8.7$ & $2.58 \pm 1.0$ & $4.58 \pm 2.5$ & $7.16 \pm 1.9$ \\
4 & $46.00 \pm 5.4$ & $2.10 \pm 0.6$ & $5.10 \pm 1.3$ & $7.20 \pm 1.5$ \\
5 & $41.42 \pm 3.2$ & $1.92 \pm 1.4$ & $5.58 \pm 1.4$ & $7.50 \pm 1.4$ \\
6 & $40.80 \pm 7.5$ & $1.90 \pm 2.7$ & $2.60 \pm 2.8$ & $4.50 \pm 3.22$ \\
\hline
\end{tabular}

\section{Mortality and pathological lesions of dead animals}

Three out of the 35 calves included in the study died, one at 22 days and two at 25 days of age. All the three animals showed increased rectal temperature for $2-$ 10 days, depression for 5-8 days, respiratory signs for 2-5 days, nasal discharge for 6-8 days, and milk refusal for 6-12 days. Body weights were $45-49 \mathrm{~kg}$, and the weight gain was very low. The animals had been treated several (7-14) times.

The lesions were the following: the diaphragmatic and cardiac lobes of the lungs were adhered to the pleura (fibrinous pleurisy), enlarged and of red colour. The cranial and cardiac lobes were affected in $100 \%$, and the diaphragmatic lobe in $40-60 \%$, by catarrhal-fibrinous pneumonic lesions, the interlobular septa were thickened with fibrin-rich oedema, and on the cut surface mucous and purulent exudate could be pressed from the bronchi. Thickened pericardium with significant quantity of fluid, slightly enlarged spleen, normal liver and kidney were found. Histological examination revealed destruction of epithelium, subacute exudative bronchopneumonia, the alveoli and bronchioles were filled with destructed neutrophils, mononuclear cells, and fibrin-rich oedema fluid. M. bovis and $P$. multocida were isolated from the lungs of all the three calves.

\section{Discussion}

This study showed that $M$. bovis infection in the tested cattle herd was an important endemic infection causing significant diseases of young calves. $M \mathrm{bo}-$ vis infection is very widespread. It was detected in about $50 \%$ of the 5 -day-old calves. Mycoplasmas could be isolated also from the vaginal swabs of the dams of calves a few days after delivery. It is known from the literature that $M$. bovis can produce mastitis (Brownlie et al., 1976) and plays a role in reproductive disorders of cows (Langford, 1977). In the herd examined, a high proportion of the 
cows had retention of fetal membranes with all its consequences. Some cows also had mastitis, abortion and stillbirth.

The role of M. bovis in the pneumonia of calves was also reported (Romváry et al., 1975). In the herd examined in this study, calves showed fever, depression, hyperpnoea, dyspnoea, nasal discharge, mild coughing, and loss of appetite, which signs were indicative of the aetiological role of $M$. bovis. These symptoms appeared at a very young age, already on the fifth day of life, then progressed gradually and reached the highest incidence at the age of 10-16 days. The affected animals did not develop normally, and their weight gain during the first 15 days of life was very poor, showing the important economical impact of the disease. If animals are left untreated, they may die due to severe fibrinous pneumonia, pleurisy, and pericarditis. The treatment could not be considered very successful, since the animals that died had previously been medicated 614 times. This is in agreement with the observations of Stalheim (1976). Even if the calves survive the disease, their growth will be retarded.

M. bovis infection was also detected in this herd five years ago. As the herd was kept closed for the last 10 years, and no new animals were introduced into the farm, it seems that M. bovis can persist for such a long time, provided that the infection was not reintroduced into the herd from time to time with bull semen. On the other hand, carrier state in connection with mastitis may continue for many months, even into the next lactation (Jasper, 1979), but the presence of M. bovis in the respiratory tract may last even longer (Ter Laak, 1992).

Pasteurella multocida was also frequently present in the herd examined, and this is in agreement with the results of several other authors. It is interesting that in our case no P. haemolytica was found. This is in contradiction with the results of others (Ball et al., 1993). P. haemolytica has been reported to act synergistically with $M$. bovis, producing very severe exudative pneumonia in calves and aggravating the disease caused by the latter (Doherty et al., 1994). The results of virus serological tests showed that the herd was also infected with various respiratory viral agents. The role of these viral infections should not be overestimated in the disease of experimental animals, since colostral antibodies were detected in calves. Considering the half-life of colostral antibodies in cattle, a considerable protection was demonstrated against IBR and PI-3 viruses (60 and $80 \%$, respectively). However, based on the lower number of BVD (5), adenovirus (6) and RS (1) seropositive calves, the role of these viruses in the respiratory symptoms could not be ruled out, as it was not possible to test paired blood samples from calves included in this experiment. 


\section{References}

Ball, H. J., Connolly, M. and Cassidy, J. (1993): Pasteurella haemolytica serotypes isolated in Northern Ireland during 1989-1991. Br. Vet. J. 149, 561-570.

Bencina, D. and Bradbury, J. M. (1992): Combination of immunofluorescence and immunoperoxidase techniques for serotyping mixture of mycoplasma species. J. Clin. Microbiol. 30, 407-410.

Brownlie, J., Howard, C. J. and Gourlay, R. N. (1976): Pathogenicity of certain mycoplasma species in the mammary gland. Res. Vet. Sci. 20, 261-266.

Doherty, M. C., McElroy, M. C., Markey, B. K., Carter, M. E. and Ball, H. J. (1994): Isolation of Mycoplasma bovis from a calf imported into the Republic of Ireland. Vet. Rec. 135, 259-260.

Ernø, H. and Stipkovits, L. (1973a): Bovine mycoplasmas: Cultural and biochemical studies. I. Acta Vet. Scand. 14, 436-449.

Ernø, H. and Stipkovits, L. (1973b): Bovine mycoplasmas: Cultural and biochemical studies. II. Acta Vet. Scand. 14, 450-463.

Hale, H. H., Helmbold, C. F., Plastridge, W. N. and Stula, E. F. (1962): Bovine mastitis caused by a Mycoplasma species. Cornell Vet. 52, 582-591.

Hirth, R. S., Nielsen, S. W. and Plastridge, W. N. (1966): Bovine salpingo-oophoritis produced with semen containing mycoplasmas. Path. Vet. 3, 616-632.

Horváth, Gy., Stipkovits, L., Zöldág, L., Varga, Zs. and Mészáros, J. (1981): Experimental mycoplasma mastitis in cattle. Acta Vet. Hung. 29, 233-236.

Jasper, D. E. (1979): Bovine mycoplasmal mastitis. J. Am. Vet. Med. Assoc. 175, 1072-1074.

Jurmanova, K. and Sterbova, J. (1977): Correlation between impaired spermatozoa motility and mycoplasma findings in bull semen. Vet. Rec. 100, 157-158.

Kissi, B., Juhász, S. and Stipkovits, L. (1985): Effect of mycoplasma contamination of bull semen on fertilisation. Acta Vet. Hung. 33, 107-117.

Langford, E. V. (1977): Mycoplasma agalactiae subsp. bovis in pneumonia and arthritis of the bovine. Can. J. Comp. Med. 41, 89-94.

Lein, D. H. (1974): Male bovine urogenital mycoplasmosis. Thesis, University of Connecticut.

Romváry, J., Rózsa, J., Stipkovits, L. and Szabó, J. (1975): Arthritis and pneumonia in cattle caused by mycoplasma (in Hungarian, with English abstract). Magyar Állatorvosok Lapja 30, 695-698.

Stalheim, O. H. V. (1976): Failure of antibiotic therapy in calves with mycoplasma arthritis and pneumonia. J. Am. Vet. Med. Assoc. 169, 1096-1097.

Stipkovits, L., Rády, M. and Glávits, R. (1993): Mycoplasmal arthritis and meningitis in calves. Acta Vet. Hung. 41, 70-89.

Ter Laak, E. A. (1992): Mycoplasma of the bovine respiratory tract. Thesis. Utrecht Univ., The Netherlands. 